\title{
PROGRESS IN ALDOSTERONISM
}

\section{A review of the prevalence of primary aldosteronism in pre-hypertension and hypertension}

\author{
George Piaditis' ${ }^{1}$ Athina Markou' ${ }^{1}$, Labrini Papanastasiou' ${ }^{1}$, loannis I Androulakis ${ }^{1,2}$ \\ and Gregory Kaltsas ${ }^{2}$
}

'Department of Endocrinology and Diabetes Center, G. Gennimatas Hospital, 154 Mesogion Avenue, 11527 Holargos, Athens, Greece and ${ }^{2}$ Department of Pathophysiology, National University of Athens, Mikras Asias 75, 11527 Athens, Greece

\author{
Correspondence \\ should be addressed \\ to G Piaditis \\ Email \\ edk-pgna@otenet.gr
}

\section{Abstract}

Primary aldosteronism (PA) secondary to excessive and/or autonomous aldosterone secretion from the renin-angiotensin system accounts for $\sim 10 \%$ of cases of hypertension and is primarily caused by bilateral adrenal hyperplasia (BAH) or aldosterone-producing adenomas (APAs). Although the diagnosis has traditionally been supported by low serum potassium levels, normokalaemic and even normotensive forms of PA have been identified expanding further the clinical phenotype. Moreover, recent evidence has shown that serum aldosterone correlates with increased blood pressure (BP) in the general population and even moderately raised aldosterone levels are linked to increased cardiovascular morbidity and mortality. In addition, aldosterone antagonists are effective in BP control even in patients without evidence of dysregulated aldosterone secretion. These findings indicate a higher prevalence of aldosterone excess among hypertensive patients than previously considered that could be attributed to disease heterogeneity, aldosterone level fluctuations related to an ACTH effect or inadequate sensitivity of current diagnostic means to identify apparent aldosterone excess. In addition, functioning aberrant receptors expressed in the adrenal tissue have been found in a subset of PA cases that could also be related to its pathogenesis. Recently a number of specific genetic alterations, mainly involving ion homeostasis across the membrane of zona glomerulosa, have been detected in $\sim 50 \%$ of patients with APAs. Although specific genotype/phenotype correlations have not been clearly identified, differential expression of these genetic alterations could also account for the wide clinical phenotype, variations in disease prevalence and performance of diagnostic tests. In the present review, we critically analyse the current means used to diagnose PA along with the role that ACTH, aberrant receptor expression and genetic alterations may exert, and provide evidence for an increased prevalence of aldosterone dysregulation in patients with essential hypertension and pre-hypertension. Hospital of Athens. His research activities involve various areas of Endocrinology, such as diseases of the thyroid gland, the reproductive system and pituitary. However in the last 8 years his main research activity has been focused on endocrine causes of arterial hypertension.

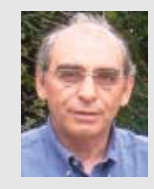




\section{Introduction}

Primary aldosteronism (PA) is the most common form of endocrine hypertension secondary to excessive or inappropriately elevated aldosterone production from the adrenals that is partially or completely autonomous of the renin-angiotensin system (RAS) $(1,2)$. The prevalence of PA varies considerably between different studies among hypertensive patients, depending on patient selection, diagnostic methodology employed and severity of arterial hypertension. Thus, a 10\% prevalence of PA was found when consecutive hypertensive patients were studied prospectively (3), whereas this figure raised to $\sim 30 \%$ when the aldosterone to renin ratio (ARR) was used as a screening test in randomly selected hypertensive patients by general practitioners (4). Clinical trials, case series and metaanalyses published up to June 2014 were critically analysed to select most appropriate literature for this review.

Although aldosterone excess is directly linked to the development of hypertension through renal sodium and water retention, it also induces tissue inflammation and an increased central sympathetic drive, with subsequent fibrosis and remodelling in critical organs such as the kidney, heart and vasculature $(3,5,6,7,8,9,10)$. As a consequence, PA leads to the development of renal impairment, atrial fibrillation, stroke and myocardial infarction $(3,11,12)$. However, due to the absence of PA-related specific symptoms and signs, there is a substantial delay in the establishment of the diagnosis that may affect the response to treatment and overall prognosis. Thus, early diagnosis is of paramount importance in order to initiate specific treatment by either surgical removal of the hyperfunctioning adrenal lesion(s) or administration of targeted medical treatment with mineralocorticoid receptor antagonists (MRAs). This notion has clearly been proven in a recent prospective study of 180 patients with PA who were treated with either adrenalectomy or MRAs and after a median follow-up of 36 months achieved normalisation of blood pressure (BP) and reversal of the detrimental left ventricular changes as shown by echocardiography (13).

Considering the high prevalence of hypertension in the general population, reliable, easy to perform and costeffective diagnostic tests are required for early diagnosis of PA. This is particularly relevant as the clinical signs and symptoms of PA are not specific, whereas hypokalaemia, which is regarded as the most distinctive biochemical feature of PA, is not always present and cases of normotensive PA have also been described $(14,15,16,17)$. However, currently available diagnostic tests for PA are complex, time-consuming, relatively expensive and cannot be applied to all hypertensive patients. A further complexity in the diagnosis of PA is the notion that at least in a subset of patients, aldosterone secretion may be modulated by the presence of functioning aberrant receptors, the diagnosis of which requires an extensive and laborious investigating protocol (18). Thus, current standard practice for the diagnosis of PA is to initially apply a screening test using the calculation of basal ARR followed by a confirmatory test to document autonomous from the RAS aldosterone secretion, such as an oral sodium loading test, saline infusion test (SIT), fludrocortisone suppression test (FST) or captopril challenge test $(16,19)$ (Table 1$)$. The use of ARR as a screening test has simplified the diagnosis of $\mathrm{PA}$, as it permits the application of diagnostic tests only to a pre-selected hypertensive population with a high probability of PA $(20,21)$. However, ARR normal cut-offs vary significantly ranging from 20 to $100 \mathrm{ng} / \mathrm{dl}$ per $\mathrm{ml}$ per $\mathrm{h}$ using an immunometric method for estimation of plasma renin activity or $68-338 \mathrm{pmol} / \mathrm{mU}$ using an immunometric method for measuring direct plasma renin concentrations, with the most commonly employed being $20-40 \mathrm{ng} / \mathrm{dl}$ per $\mathrm{ml}$ per $\mathrm{h}$ or $68-135 \mathrm{pmol} / \mathrm{mU}$, respectively, when performed in the morning on seated ambulatory patients $(8,20)$.

This wide variation in the normal ARR cut-offs affects the performance of diagnostic tests for PA and thus the estimated prevalence of PA in hypertension. As a result the Endocrine Society's clinical practice guidelines do not specify which of these four confirmatory tests should be regarded as the 'gold standard' test to definitely confirm or exclude PA (20), and thus different tests are used by different centres. For example, at the Mayo Clinic the 3-day oral salt loading test is used to diagnose PA when on the 3rd day 24-h urinary aldosterone measurement is higher than $12 \mu \mathrm{g} /$ day, provided that 24 -h sodium excretion exceeds $200 \mathrm{mEq} /$ day (15). In contrast, in a large prospective study, the $50 \mathrm{mg}$ captopril test was found to be equally effective to the SIT in hypertensive patients with aldosterone-producing adenomas (APAs). However, its diagnostic value is limited if the sodium intake is $\leq 130 \mathrm{mEq}$ /day (3). On the basis of these findings, some recommend the use of the captopril test in patients with increased daily sodium intake (22), particularly when the ARR is high (23). On the other hand, others have shown that the captopril test may give misleading results $(24,25,26)$. Although the FST is regarded by some as the 
Table 1 Tests employed for the confirmation of the diagnosis of PA.

Test

Oral salt loading test
$(15,16,19,21,72)$

Recumbent-saline infusion test (SIT) $(16,19,21,72)$

Fludrocortisone suppression test (FST) $(16,19,21,72)$

Fludrocortisone dexamethasone suppression test (FDST) (61)

Recumbent post-low dose dexamethasone suppression (LDDST)-saline infusion test (PD-SIT) (60)

\section{Methodology}

Sodium intake $>200 \mathrm{mmol}(6 \mathrm{~g})$ for 3 days substantiated by $24-\mathrm{h}$ urine sodium collection ( $>200 \mathrm{mmol}$ ). Adequate potassium chlorate supplementation to maintain potassium within normal range. 24-h urinary aldosterone is collected from the morning of day 3 till morning day 4

Maintain recumbent position at least $1 \mathrm{~h}$ before and during the infusion of $210.9 \%$ normal saline infused intravenously over $4 \mathrm{~h}$. Sampling for renin, aldosterone and potassium drawn before initiation of infusion and after $4 \mathrm{~h}$ with continuous monitoring of $\mathrm{BP}$ and heart rate Administration of sodium chloride ( $2 \mathrm{~g}$ three times daily with food) plus oral fludrocortisone $(0.1 \mathrm{mg}$ every $6 \mathrm{~h}$ for 4 days) along with potassium chlorate (30 mmol three times daily) to maintain serum potassium $>4 \mathrm{mmol} / \mathrm{l}$

Administration $25-50 \mathrm{mg}$ captopril per os after remaining sitting or standing for at least $1 \mathrm{~h}$. Measurement of PRA and plasma aldosterone and cortisol before and 1 and $2 \mathrm{~h}$ post captopril administration

Administration of sodium chloride $(2 \mathrm{~g}$ three times daily with food) plus oral fludrocortisone $(0.1 \mathrm{mg}$ every $6 \mathrm{~h}$ for 4 days) along with potassium gluconate ( $4.68 \mathrm{~g}$ three times daily) to maintain serum potassium within the normal range (3.5-5.5 mEql/l). At midnight on the 4th day $2 \mathrm{mg}$ of dexamethasone are added ( $2 \mathrm{~h}$ after dinner)

LDDST: dexamethasone administration $2 \mathrm{mg} /$ day $(0.5 \mathrm{mg} / 6 \mathrm{~h})$ for 2 consecutive days. Maintain recumbent position early in the morning of the 3rd day $(0830 \mathrm{~h})$ and during the i.v. infusion of 2 I $0.9 \%$ normal saline over $4 \mathrm{~h}$. Sampling for renin, aldosterone, cortisol and potassium drawn before initiation of infusion and after $4 \mathrm{~h}$ with continuous monitoring of $\mathrm{BP}$ and heart rate

\section{Interpretation}

Normal: urinary aldosterone secretion $<10 \mu \mathrm{g} / 24 \mathrm{~h}$. PA: urinary aldosterone excretion $>12 \mu \mathrm{g} / 24 \mathrm{~h}$

\section{Post-infusion plasma} aldosterone $<5 \mathrm{ng} / \mathrm{dl}$ makes PA unlikely, whereas levels $>10 \mathrm{ng} / \mathrm{dl}$ confirms the diagnosis. Values between 5 and $10 \mathrm{ng} / \mathrm{dl}$ are indeterminate

Upright plasma aldosterone $>6 \mathrm{ng} / \mathrm{dl}$ on day 5 at $1000 \mathrm{~h}$ confirms PA (concomitant PRA $<1 \mathrm{ng} / \mathrm{ml}$ per $\mathrm{h}$ ) and plasma cortisol lower than the value measured at $0700 \mathrm{~h}$ (exclude a confounding ACTH effect)

Normal: post-captopril aldosterone $<12-13.9 \mathrm{ng} / \mathrm{dl}$ or post-captopril A/R $<26-30 \mathrm{ng} / \mathrm{dl}$ per $\mathrm{ng}$ per $\mathrm{ml}$ per h or $<200 \mathrm{pg} / \mathrm{ml}$ per ng per $\mathrm{ml} / \mathrm{h}$

Upright plasma aldosterone $>82 \mathrm{pmol} / \mathrm{l}$ and ARR $>26 \mathrm{pmol} / \mathrm{mU}$ on day 5 at $0830 \mathrm{~h}$ confirms PA. Simultaneous cortisol measurements $(<54 \mathrm{nmol} / \mathrm{l})$ are required to confirm patients' compliance

Post-infusion plasma aldosterone $<68 \mathrm{pmol} / \mathrm{l}$ and ARR $<10 \mathrm{pmol} / \mathrm{mU}$ confirms PA. Cortisol measurements $(<30 \mathrm{nmol} / \mathrm{l})$ are required to confirm patients' compliance
Potential side effects, contraindications and limitations

Contraindicated in severe cardiac or renal failure. Reliability of the test is higher if urinary aldosterone is measured by mass spectrometry

The test is contraindicated in patients with uncontrolled hypertension, cardiac and renal insufficiency, cardiac arrhythmias and severe hypokalaemia

The test can be conducted as in-patient for close monitoring or as out-patient in motivated/cooperative patients. Normal: plasma aldosterone level $<6 \mathrm{ng} / \mathrm{dl}$ taken at $1000 \mathrm{~h}$ in an ambulatory patient on day 4 (single centre data)

The test is recommended to be used in patients on an adequate sodium intake ( $>133 \mathrm{mEq}$ or $6.3 \mathrm{~g} \mathrm{NaCl} /$ day)

The test can be conducted as in-patient for close monitoring or as out-patient in motivated/cooperative patients who are on antihypertensive treatment with calcium channel blockers with no or minimal effect on hormonal measurements.

The test is contraindicated in patients with uncontrolled hypertension, cardiac and renal insufficiency, cardiac arrhythmias and severe hypokalaemia

PA, primary aldosteronism; BP, blood pressure; LDDST, low dose dexamethasone suppression test.

most reliable confirmatory test (16), it has recently been shown that the seated SIT is almost equally effective to FST, while the recumbent-SIT, which is used in the majority of studies, failed to diagnose PA in $67 \%$ of the tested cases (27). However, similar to the wide normal cut-off variation in ARR, the cut-offs of post-SIT or postFST aldosterone levels also vary widely, ranging from 139 to $277 \mathrm{pmol} / \mathrm{l}(15,20,24)$. 


\section{Genetic determinants of PA}

Besides the high prevalence of PA, specific genetic alterations involved in its pathogenesis had been identified only for the rare familial forms of the disease mainly familial hyperaldosteronism (FH) type 1 . This form of PA results from an unequal crossing over between the highly homologous CYP11B2 and CYP11B1 genes that code for aldosterone synthase and steroid 11ß-hydroxylase, producing a chimeric gene that is under adrenocorticotrophin (ACTH) rather than RAS control $(28,29,30)$. Another form of FH with no response to dexamethasone suppression, that is biochemically and clinically similar to sporadic PA, has also been described. This has been designated as FH type 2, being autosomal dominantly transmitted, is considered heterogenous and although no precise molecular basis has been found, there is a suggestion for a link with chromosomal region 7p22 (31). An important breakthrough in the molecular pathogenesis of PA was made by Choi et al. (32) by performing wholegenomic sequence identified mutations in the gene encoding the inwardly rectifying potassium channel Kir3.4 (KCNJ5) in patients with APAs (30). Subsequently, mutations in three further genes encoding for membrane proteins (the $\mathrm{Na} / \mathrm{K}-\mathrm{ATPase}$ (ATP1A1), the Ca ATPase (ATP2B3), and Ca1.3 (CACNAID)) have been described $(33,34,35)$. The altered proteins are associated with $\mathrm{Ca}$ influx and/or activated Ca signalling pathways leading to hyperproduction of aldosterone by CYP11B2 and in some cases zona glomerulosa cell hyperplasia or adenoma formation (28). In addition, KCNJ5 mutations have been shown to represent the underlying genetic event in $\mathrm{FH}$ type $3(32,36)$. Further studies in a large number of patients with APAs revealed that somatic mutations in the KCNJ5, ATP1A1, ATP2B3 or CACNAID genes are present in more than half of them ( $\sim 40,6,1$ and $8 \%$ respectively) (31). However, although in all these genetic alterations the end point is Ca influx and membrane depolarisation leading to aldosterone hypersecretion, there are substantial differences in the clinical and biochemical phenotypes related to specific genetic alterations. In particular, patients with PA harbouring KNCJ5 mutations are more frequently female and generally younger compared with non-mutated patients, suggesting earlier onset and/or more severe disease $(37,38,39,40)$. In addition, in some studies higher aldosterone and lower potassium levels at diagnosis have been described and larger tumours were found compared with non-mutated cases $(37,38,39,40,41)$. Conversely, in some but not all studies, it has been shown that patients harbouring ATPase mutations are more commonly men and are associated with the most severe forms of PA and rather smaller size tumours $(30,39)$. These findings are particularly relevant in the familial form of PA (FH type 3) where specific mutations in the KJNC5 gene, as those altering the G151E amino acid, are associated with mild aldosteronism compared with those with G151R mutation that have a more severe clinical phenotype $(28,32)$. Likewise, histopathology is also quite heterogenous ranging from micro- or macronodular hyperplasia to adenoma formation, whereas the adjacent adrenal cortex may be atrophic, diffuse hyperplastic or nodular hyperplastic $(37,42)$. In particular, subjects with the G151E mutation have no hyperplasia in the surrounding tissue because there is increased cell death limiting the glomeruloma mass that is still able to produce aldosterone but does not evolve into progressive disease $(28,37)$. In contrast to APAs, no KCNJ5 or ATP1A1 and ATP2B3 mutations have been found in 174 and 91 patients with PA due to bilateral adrenal hyperplasia (BAH) respectively $(30,37)$. More recently a common single-nucleotide polymorphism (c.-2G $>$ C) of the NR3C2 gene, coding for the MR, has been found to be associated with increased activation of the RAS and increased BP in the general population, connoting vulnerability for hypertension (43).

\section{Evidence in favour of an ACTH role in aldosterone regulation}

It is generally accepted that the main regulators of aldosterone secretion are the RAS and serum potassium levels, whereas ACTH is thought to exert a relatively minor effect. Previous studies have shown that chronic low-dose ACTH infusion in humans increases aldosterone levels within the first $12-36 \mathrm{~h}$ followed by a slow decline over the next several days (44) with the minimal effective dose of infused ACTH being extremely low (0.03 $\mu$ g) (45). Similar data have been obtained from in vitro studies that have demonstrated ACTH-responsive effects on the expression of genes responsible for aldosterone production $(46,47)$. Additional evidence of the ACTH role in aldosterone secretion is derived from patients with ACTH resistance syndrome who develop severe salt-losing adrenal hypoplasia due to loss-of-function mutations of the $A C T H$ receptor $(A C T H-R)$ (MC2R) (48). These data suggest that although ACTH may not be the principal regulator, it exerts a significant, at least short-lasting stimulatory effect on aldosterone secretion and a similar genomic effect on adrenal glomerulosa cells. In favour of such a potential ACTH effect is the finding that the highest $A C T H-R$ mRNA expression in adrencortical tumours is found in APAs 
$(49,50,51)$. Indeed, aldosterone secretion, although relatively unresponsive to postural studies in such patients, exhibits an ACTH-dependent diurnal rhythm and responds to dexamethasone suppression $(52,53,54)$. Moreover, the aldosterone response to ACTH-related physical and/or psychological stress has never been investigated in patients with hypertension. We have recently reported that the cortisol response to ACTH in patients with apparently non-secreting adrenal adenomas is correlated significantly with carotid intima-media thickness (IMT) and flow-mediated dilatation (FMD) in the brachial artery (55). Considering that ACTH is a natural stimulus of aldosterone secretion, similar ACTHstress mediated alterations in aldosterone secretion could also be expected. This is supported by studies where the effect of graded intensities treadmill exercise (corresponding to 50, 70 and $90 \%$ of maximum oxygen uptake, $\mathrm{VO}_{2}$ max $)$ on aldosterone secretion was examined $(56,57)$. A significant aldosterone response was observed even with mild exercise ( $50 \% \mathrm{VO}_{2 \max }$ ), while the maximum response was observed with moderate exercise $\left(70 \% \mathrm{VO}_{2 \max }\right)(57)$. During these studies, cortisol levels remained unchanged at mild exercise, suggesting that the adrenal cortex more readily secretes aldosterone than cortisol in response to physical stress. This ACTH-related effect could be further enhanced by the presence of particular polymorphisms of the CYP11B2 gene associated with increased synthase activity leading to higher aldosterone levels and contributing to increased risk of developing aldosteronerelated hypertension and cardiovascular disease in the general population $(58,59)$.

Considering these data, it can be reasonably assumed that even mild alterations in ACTH secretion, as encountered during physical or psychological daily stresses, can induce ACTH-mediated aldosterone hypersecretion. Indeed, some investigators have recognised this possible ACTH effect on aldosterone secretion from the adrenals as a potential confounding factor that could affect the performance characteristics of currently used confirmatory tests for PA (16). In order to overcome this potential confounding effect, the simultaneous aldosterone and cortisol measurement during the FST has been introduced to ensure that the test is not performed under stressful conditions secondary to ACTH fluctuations (16). Therefore, it is reasonable to suggest that if the diagnostic tests for PA are performed after dexamethasone administration in order to eliminate any ACTH stimulatory effect on aldosterone secretion, their diagnostic accuracy could be substantially improved. Based on this concept, we have modified the traditional FST by adding $2 \mathrm{mg}$ of dexamethasone (frudrocortisone dexamethasone suppression test (FDST)) at midnight of the 4th day of the test and the SIT by performing the test early in the morning following a low dose dexamethasone suppression test (LDDST) (post dexamethasone-saline infusion test (PD-SIT)) (60, 61). Furthermore, a number of other aberrant eutopic or ectopic membrane-bound G-protein-coupled receptors (GPCRs) have been found to be expressed in the adrenal cortex that could regulate aldosterone hypersecretion by an independent from the RAS albeit not autonomous manner (18). These aberrant GPCRs are expressed in all three streroidogenic zones of the adrenal gland and activate the same cascade of cellular events as ACTH following interaction with the ACTH-R (18). Using microarray analysis of APAs and cortisol-secreting adenomas in comparison with normal adrenals, the GPCRs that were found to have the highest expression were the luteinising hormone (LH) receptor, 5-hydroxy-tryptamine 4-receptor (5HT4R), gonadotrophin-releasing hormone (GNRH) receptor, glutamate receptor metabotropic 3 , endothelin receptor type-B-like protein and ACTH-R, whereas their expression was higher in APAs compared with cortisolsecreting adenomas (62). Furthermore, in vivo and in vitro studies in patients with PA showed that aldosterone secretion was aberrantly regulated by several GPCRs albeit with substantial diversity of the receptors involved; of interest, aldosterone hypersecreting tissues exhibited ectopically expressed GNRH (4/15) and thyroid-releasing hormone (TRH) (1/15) mRNA that correlated with in vivo responses in a subset of patients studied $(18,51,54)$. In favour of the role of these receptors are cases of PA that developed during pregnancy and were responsive to LH stimulation (63). The notion that the expression of aberrant receptors may be directly involved in the pathogenesis of PA is attractive as treatment targeting such receptors could have a therapeutic effect. However, the application of non-specific 5HT4R inhibitors (cyproheptadine and ketanserin) $(64,65)$ had only a transient and not sustainable effect on aldosterone secretion similarly to V1-receptor antagonist (66) and endothelin-1 ETA, B receptor inhibitors administration (67). Considering these findings and the recent advances in molecular pathogenesis of APAs, it is rather unlikely that the expression of aberrant GPCRs is directly linked with the development of at least APAs. However, their presence could potentially have an effect in some of the diagnostic tests of PA, such as the ARR with regard to posture and menstrual cycle in females, saline infusion in the presence of AVPR $1 \mathrm{~A}$, whereas a link between the expression of such receptors and potassium and calcium channel mutations cannot be excluded. 


\section{Potential limitations of currently employed diagnostic tests of PA}

Currently existing cut-offs of both screening and diagnostic tests for PA have been obtained from apparently 'normal' individuals, in whom no imaging studies of the adrenal glands were performed. However, considering the high prevalence of adrenocortical adenomas in the general population (68) and the presence of dysregulated aldosterone secretion in a proportion of them (69), it is possible that individuals with adrenocortical adenomas and subclinical aldosterone excess could have been included among those regarded as 'normal controls'. This view is supported by the findings of our recent study which revealed that seven out of 79 (8.8\%) normotensive individuals who served as controls had a single adrenal adenoma on abdominal computerised tomography (CT) (61). In addition, functional studies revealed that four of them had also PA, as their post-FDST aldosterone levels were significantly higher, ranging from 82 to $168 \mathrm{pmol} / \mathrm{l}$, compared with the cut-off level of $74 \mathrm{pmol} / \mathrm{l}$ obtained from individuals with normal adrenal imaging (61). Even more, there is evidence suggesting that PA may also be present in normotensive individuals without adrenal adenomas, resulting in even higher aldosterone cut-offs used to exclude PA, and therefore an underestimation of the overall prevalence of PA in patients with hypertension (17). These findings necessitate the adoption of strict selection of a control group by recruiting individuals with normal BP and normal adrenal imaging $(60,61)$. Furthermore, the interpretation of currently available diagnostic tests could also affect the prevalence of PA. To date the procedure adopted by almost all studies is to estimate the ARR using pre-screened hypertensive populations, in whom the diagnosis of PA has been made by a confirmatory test and/or adrenal venous sampling (AVS). However, this approach may be hampered by the fact that the final diagnosis of PA is highly dependent on the specificity of preceding screening tests, mostly the ARR (70). A more appropriate approach would have been to diagnose PA retrospectively by performing confirmatory testing to both hypertensive and non-hypertensive (control group) populations regardless of the results of a screening test. There is only a single study that has adopted this approach using a community-based sample of 118 Caucasian hypertensive patients (71). The estimated specificity of ARR was found to vary from 71 to $84 \%$, with a concomitant sensitivity ranging from 73 to $93 \%$, whereas the prevalence of PA was found to be $13 \%$ (71). However, in that study the diagnosis of PA was only made by measuring 24-h urinary aldosterone excretion, whereas the control group was not tested for the presence of adrenal adenomas, and the ACTH effect on aldosterone secretion was not considered.

All these factors contribute to the current difficulty in making the diagnosis and the wide variation of the recorded prevalence of PA. In addition, the available diagnostic tools are cumbersome and disease's epidemiology appears to be a continuous spectrum from low-renin hypertension, normotensive forms of normokalaemic PA to hypokalaemic PA, making the establishment of cut-offs used to make the diagnosis rather arbitrary $(28,72)$.

\section{Prevalence of PA in hypertension and pre-hypertension}

Recent epidemiological studies have shown that serum aldosterone and renin levels and the ARR correlate with increased BP and the incidence of hypertension in the general population $(73,74)$, suggesting that alterations in aldosterone production may be directly related to BP elevation in a significant proportion of hypertensive individuals. As already mentioned, several cross-sectional and prospective studies in unselected hypertensive populations have shown that the prevalence of PA is much higher than previously believed, although it varies significantly between studies ranging from 4.6 to $16.6 \%$ when confirmatory tests to diagnose PA were used (Table 2) $(5,6,7,8,21,71,75,76,77,78,79,80,81,82)$. However, in patients with resistant hypertension, the prevalence of PA is reported to be even higher ranging from 17 to $23 \%(16,83)$. This view of a step-wise increase in the prevalence of PA according to the severity of systolic and diastolic BP elevation (SBP and DBP respectively) is substantiated further by the findings of Mosso et al. (77) who reported that the prevalence of PA increases with the severity (stage) of hypertension as defined by the Joint National Committee VI. According to their findings, the estimated prevalence of PA for stage 1 hypertension (SBP $140-159 \mathrm{mmHg}$, DBP $90-99 \mathrm{mmHg}$ ) is $1.99 \%$, for stage 2 (SBP $160-179 \mathrm{mmHg}$, DBP $100-109 \mathrm{mmHg}$ ) $8.02 \%$, and for stage 3 (SBP > $180 \mathrm{mmHg}$, DBP > $110 \mathrm{mmHg}$ ) 13.2\% respectively. In addition, NAHANES from 1999 to 2006 estimated that $30 \%$ of adults above 20 years of age have pre-hypertension, which is defined as an untreated SBP of $120-139 \mathrm{mmHg}$, or an untreated DBP of $80-89 \mathrm{mmHg}$, and that $\sim 15 \%$ of them have secondary hypertension the most common cause being PA (84). This is important as the prevalence of cardiovascular complications associated with PA is disproportionally higher than predicted by $\mathrm{BP}$ measurement alone, whereas PA is considered as a 
Table 2 Prevalence of primary aldosteronism in hypertension.

\begin{tabular}{lr}
\hline Reference & $\begin{array}{c}\text { Number of } \\
\text { patients }\end{array}$ \\
\cline { 1 - 1 }$(5)$ & 199 \\
$(75)$ & 495 \\
$(6)$ & 350 \\
$(7)$ & 305 \\
(77) & 300 \\
(81) & 609 \\
(8) Torino, Italy & 345 \\
(8) Rochester, Minnesota & 7343 \\
(8) Singapore & 1112 \\
(8) Santiago, Chile & 3850 \\
(71) & 914 \\
& 118 \\
(79) & \\
& \\
(82) & \\
(80) & 1125 \\
(78) & 200 \\
& 327 \\
\hline
\end{tabular}

\begin{tabular}{|c|c|}
\hline Threshold of confirmatory test & $\begin{array}{c}\text { Prevalence } \\
(\%)\end{array}$ \\
\hline FST ALD > $166 \mathrm{pmol} / \mathrm{l}$ & 8.5 \\
\hline FST, ALD > $140 \mathrm{pmol} / \mathrm{l}$ & 9.2 \\
\hline Seated-SIT, ALD > $277 \mathrm{pmol} / \mathrm{l}$ & 5.0 \\
\hline FST, ALD > $140 \mathrm{pmol} / \mathrm{l}$ & 9.5 \\
\hline FST ALD > $166 \mathrm{pmol} / \mathrm{l}$ & 18 \\
\hline FST, ALD > $140 \mathrm{pmol} / \mathrm{l}$ & 6.1 \\
\hline SIT, ALD > $236 \mathrm{pmol} / \mathrm{l}$ & 14.2 \\
\hline SIT, ALD > $140 \mathrm{pmol} / \mathrm{l}$ & 8.0 \\
\hline $\begin{array}{l}\text { Oral sodium load/post-test } \\
\quad 24 \text { h-urinary ALD }>12 \mu \mathrm{g} / \text { day }\end{array}$ & 10.8 \\
\hline SIT, ALD > $277 \mathrm{pmol} / \mathrm{l}$ & 4.6 \\
\hline FST, ALD > $140 \mathrm{pmol} / \mathrm{l}$ & 7.2 \\
\hline $\begin{array}{l}\text { Oral sodium load/post-test } \\
24 \text { h-urinary ALD }>12 \mu \mathrm{g} / \text { day }\end{array}$ & 13.0 \\
\hline Captopril test $(50 \mathrm{mg})$ & 11.2 \\
\hline $\begin{array}{l}\mathrm{SIT}, \mathrm{ALD}>140 \mathrm{pmol} / \mathrm{l} \\
\mathrm{FST}, \mathrm{ALD}>160 \mathrm{pmol} / \mathrm{l}\end{array}$ & $\begin{array}{l}0.9 \\
5.5\end{array}$ \\
\hline $\begin{array}{c}\text { FDST, ALD }>74 \mathrm{pmol} / / \mathrm{plus} \\
\text { ALD/REN }>32 \mathrm{pmol} / \mathrm{mU}\end{array}$ & 29 \\
\hline
\end{tabular}

\begin{tabular}{c}
\hline APA (\%) \\
\hline $5 / 17(29)$ \\
$5 / 43(12)$ \\
$6 / 16(37.5)$ \\
$1 / 29(3.5)$ \\
$15 / 49(31)$ \\
$2 / 37(5.4)$
\end{tabular}

$170 / 587(29)$

$34 / 120(28)$

$88 / 177(50)$
$6 / 66(9.1)$

$54 / 126(43)$

13/69 (19)

\section{Origin}

Hypertension Unit Hypertension Unit

Primary Care Clinic

Primary Care Clinic

Hypertension Unit

Primary Care Clinic

Hypertension Unit

Hypertension Unit

Endocrine Unit

Endocrine Unit

Endocrine Unit

Population-based Cohort

14 Hypertension

Centres

Hypertension Unit

Endocrine Unit

FST, fludrocortisone suppression test; SIT, saline infusion test; FDST, fludrocortisone dexamethasone suppression test.

multisystem disease where aldosterone excess directly or indirectly affects several organs (85).

Many methodological factors may be responsible for this wide variation in the prevalence of PA in patients with hypertension, as they can interfere with renin and/or aldosterone measurements affecting the diagnostic accuracy of both screening and diagnostic tests. Factors such as posture at the time of sampling, serum potassium levels, renin/aldosterone assays employed, renal function, gender, age and use of anti-hypertensive drugs are all known to be implicated and have extensively been analysed in many recent relevant reviews $(15,16)$. In addition, heterogeneity in clinical expression of genes recently found to be implicated in PA secondary to APAs and/or presence of aberrant receptors could lead to alterations of aldosterone biosynthesis and differences in aldosterone levels $(18,28,86)$. Indeed, in the Framingham Heart Study on the aldosterone heritability levels, the proportion of variation in the population that is related to genetic differences was $11 \%$ and that of renin's and ARR was 22 and $40 \%$ respectively (73).

\section{Evidence in favour of an increased prevalence of PA in hypertension and pre-hypertension}

The genetic variability of APAs, the unaccounted ACTH effect in currently existing tests and the absence of a well-defined control group could all operate to shift the normal cut-offs of both screening and diagnostic tests of PA to higher values leading to a significant underestimation of the prevalence of PA in patients with hypertension. We have recently studied 180 unselected hypertensive patients and compared them with 72 matched non-hypertensive individuals with normal adrenal imaging (61). The diagnosis of PA was confirmed using the FDST, thus eliminating any ACTH effect on aldosterone secretion. This test was performed on both controls and hypertensive patients, regardless of ARR values, and the calculated normal cut-off of basal ARR was found to be $84 \mathrm{pmol} / \mathrm{mU}$. The simultaneous estimation of both post-FDST aldosterone levels and ARR was employed to define the diagnosis of PA, using as normal cut-offs the $74 \mathrm{pmol} / \mathrm{l}$ and $32 \mathrm{pmol} / \mathrm{mU}$ respectively obtained from the control group (61). Using this approach, the mean post-FDST aldosterone levels and ARR were found to be much higher in hypertensive patients than controls (Fig. 1) and correlated significantly with both SBP and DBP (Fig. 2), whereas the estimated prevalence of PA was found to be $31 \%(56 / 180)$. In contrast, relying solely on basal ARR, only $7.2 \%$ (13/180) of the hypertensive individuals were considered to have PA which was confirmed by the FDST in ten of them (10/180, 5.5\%). In the remaining three patients, the diagnosis of PA was not confirmed either due to an unaccounted ACTH surge or due to a false-positive ARR increasing the population requiring unnecessary confirmatory testing to ascertain 

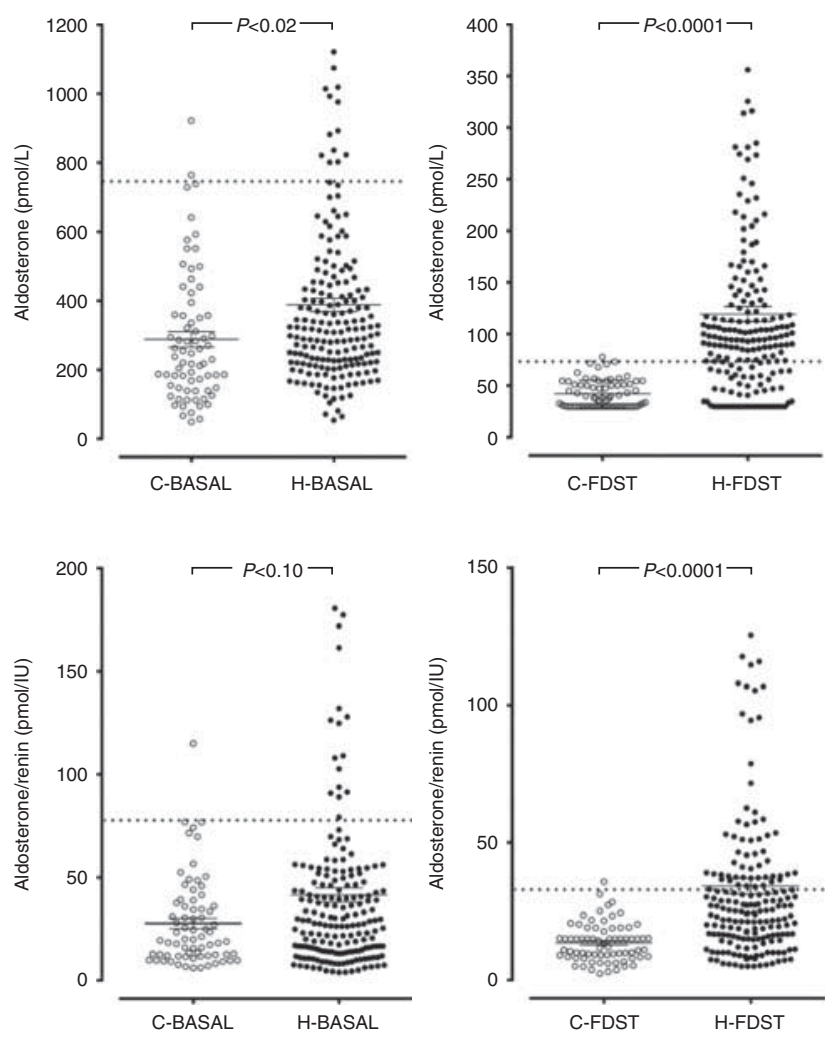

\section{Figure 1}

Basal and post-FDST aldosterone levels (ALD) and aldosterone:renin ratio (ARR) in controls $(C)$ and hypertensives $(H)$.

the diagnosis. The sensitivity and specificity of basal ARR were found to be 18 and $98 \%$ respectively, considerably different from those published so far $(16,70,87)$. These findings suggest that the use of basal ARR alone permits the detection of more advanced cases of PA leaving milder forms undiagnosed. A major limitation of this study is that the FDST was not compared directly with the classical FST in order to document that the addition of dexamethasone indeed improves the performance characteristics of the test. However, when the PD-SIT was compared with the classical SIT in a previous study, a much higher prevalence of PA, $24 \%$ vs $11 \%$, was found in 151 patients with adrenal adenomas (60). These results suggest that dexamethasone administration is expected to have a similar beneficial effect on the performance characteristics of FST and support the view that both the ACTH and renin stimulatory effects on aldosterone secretion need to be considered for making the diagnosis $(60,61)$.

These results have recently been confirmed by expanding our initial study including a much higher number of individuals (327 hypertensive and 100 controls) (78).
However, the normal basal ARR cut-off obtained from the latest study was significantly lower than previously defined $(67.5 \mathrm{pmol} / \mathrm{mU}$ vs $84 \mathrm{pmol} / \mathrm{mU})$, resulting in a higher sensitivity (35\% vs $7.2 \%$ ). Similarly, the cut-off value of post-FDST ARR was also lower $(26 \mathrm{pmol} / \mathrm{mU}$ vs $32 \mathrm{pmol} / \mathrm{mU})$, whereas the post-FDST aldosterone levels were higher $(82 \mathrm{pmol} / 1$ vs $74 \mathrm{pmol} / \mathrm{l})$ albeit without alteration in the prevalence of PA that was found to be $29 \%$ (78). The observed different test characteristics in the last study may be attributed to the higher number of controls included and the stricter selection criteria adopted. We subsequently followed up 122 nonhypertensive individuals, 100 of whom have completed a mean follow-up period of 5 years (17). Thirteen of these individuals had findings consistent with PA at initial assessment and 11 (85\%) developed hypertension, whereas only 20 of the 87 individuals without PA (23\%) developed hypertension (odds ratio: 18.42, 95\% CI: 3.76-90.10, $P$ : 0.0001) (Fig. 3). On the basis of these findings, only individuals who remained normotensive during the
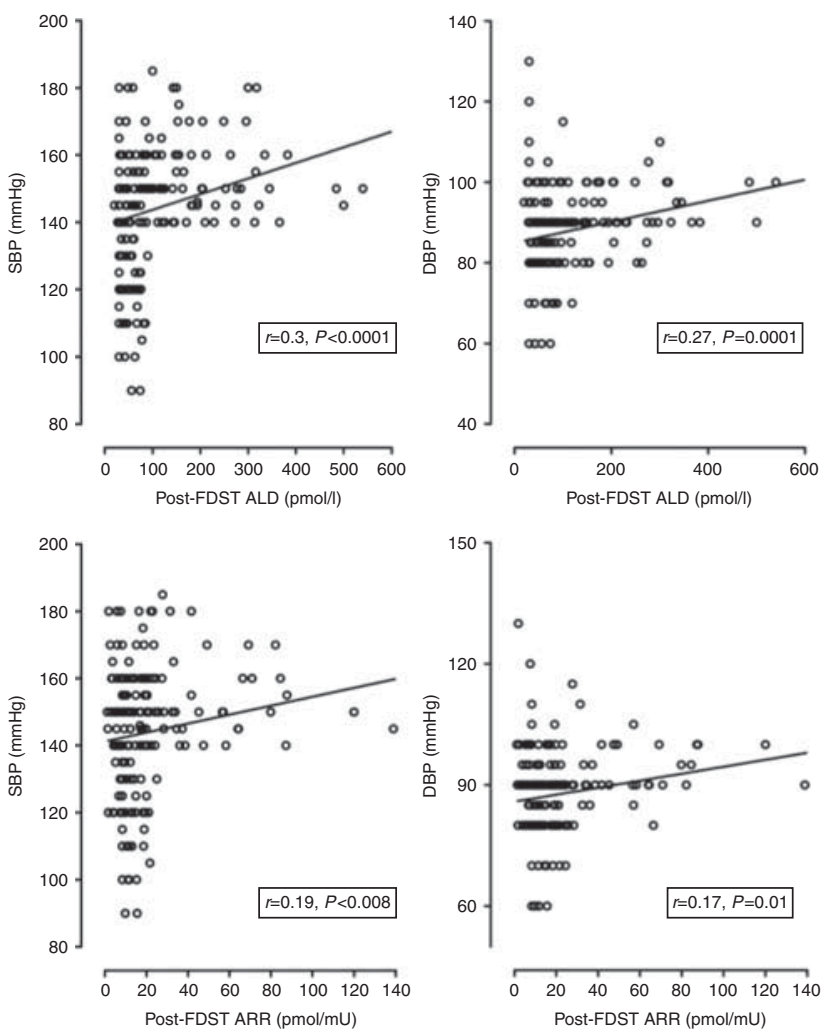

Figure 2

Linear relationship between systolic/diastolic blood pressure (SBP, DBP) and the post-FDST aldosterone levels (ALD) and aldosterone:renin ratio (ARR). 

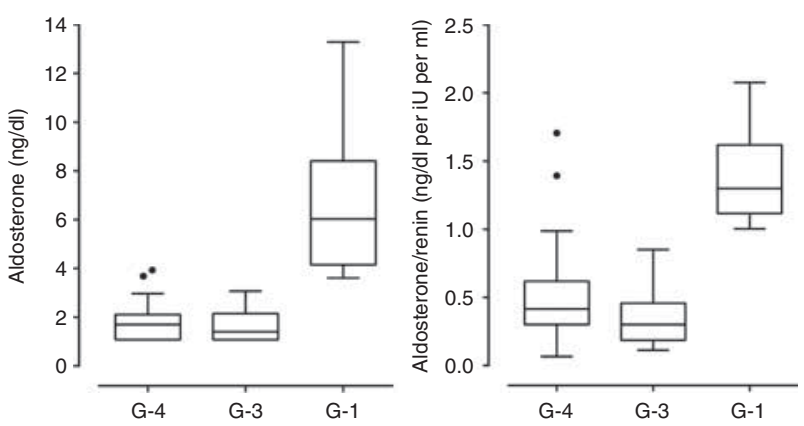

\section{Figure 3}

Box and whisker-Tukey plot. Post-FDST aldosterone levels and aldosterone:renin ratio in all subgroups of controls $(n=100)$ who were followed up for a mean of 5 years are shown. G-4 is the group of controls without PA who remained normotensive ( $n=67) ; \mathrm{G}-1$ is the group of controls with PA $(n=11)$ who developed hypertension; G-3 is the group of controls without PA $(n=20)$ who developed hypertension. The controls with PA $(\mathrm{G}-2, n=2)$ who remained normotensive are indicated by the two black circles. The horizontal lines represent the mean values, whereas the vertical ones represent the 2.5-97.5 percentiles.

follow-up period were used to define the new tests, characteristics and estimate the prevalence of PA in patients with hypertension. Sixty-nine patients who were considered to have PA were treated with MRAs, obtaining a significant reduction in both SBP and DBP levels (mean reduction $28 \pm 18$ and $14 \pm 10 \mathrm{mmHg}$ respectively).

Indirect data for MR activation in patients with hypertension has previously been reported by Levy et al. (88). In that double-blind, randomised, multicentre and placebo-controlled study of 397 patients with mild-tomoderate hypertension, the anti-hypertensive effect of titrated doses of eplerenone (50-200 mg/day) was evaluated. Approximately, $80 \%$ of patients obtained adequate BP control, with the majority using the lowest dose, and only $20 \%$ failed to respond (88). Although the presence of PA was not evaluated, these results highly suggest that MR activation may be implicated in the development of hypertension as eplerenone is a highly selective MR antagonist. Other studies have also shown that eplerenone or spironolactone, either alone or in combination with other anti-hypertensive drugs, are both highly effective in improving arterial BP, renal function, arterial stiffness and left ventricular function in patients with hypertension $(89,90)$. Although effectiveness of MRA could be related to relative or absolute aldosterone excess, cortisol could also be implicated as an additional MR activator, as in some tissues such as the heart, the activity of 11ß-hydroxysteroid dehydrogenase type 2 is too low (91). However, this notion remains to be investigated by further studies.

Considering that resistant hypertension is found in up to $16 \%$ (92) of hypertensive patients, it is prudent to suggest that with the currently employed diagnostic procedures a significant proportion of patients with PA remain undiagnosed. However, the wide application of confirmatory tests to reveal states of altered aldosterone dynamics in patients with hypertension although clinically meaningful is cost-ineffective. This view has previously been put forward by Funder (93) who proposed an alternative approach by introducing low-dose MRAs as part of first-line therapy for hypertension, reserving the use of screening and diagnostic tests for selected hypertensive populations.

Although the natural history of PA is well known, there is limited information regarding its evolution. It is reasonable to consider that PA develops from an initially small-sized lesion with undetectable (by current means) dysregulated aldosterone secretion which then evolves over time into the full biochemical and clinical phenotype of PA. During this period, autonomous from the RAS or altered aldosterone secretion may be present as a state of 'subclinical $\mathrm{PA}^{\prime}$ '. Such sub-clinical forms of PA can be expected to exist even in apparently normal non-hypertensive individuals, resembling those found in subclinical primary hyperparathyroidism, hyperthyroidism and hypercortisolism that are also associated with dysregulated albeit within normal limit calcium, thyroid hormone and cortisol levels respectively $(94,95)$. However, the prevalence of subclinical or established PA in pre-hypertension, and even more its clinical significance, remains largely unknown as aldosterone and renin measurements are not performed routinely in normotensive individuals.

The first case of normotensive PA was described in 1972 in a young non-hypertensive man with a rapidly growing adrenal carcinoma, who was presented with disabling myopathy and severe hypokalaemia (96). Since then, several normotensive cases of PA have been published with hypokalaemia and adrenal adenomas being the most consistent findings (97). We have also recently reported that PA was found in $12 \%$ of normotensive and normokalaemic patients with adrenal incidentalomas (98). However, there is increasing evidence that normotensive PA may be found in individuals without hypokalaemia or adrenal adenomas. Stowasser et al. (99) have previously described ten patients with familial PA type I, who 
remained normotensive after a 5-year follow-up period. An interesting observation made by the same group was that increased left ventricular wall thicknesses and reduced diastolic function found in eight normotensive patients with genetically proven glucocorticoid-suppressible PA (100). This is the first clinical study showing that cardiac dysfunction is associated with aldosterone excess in the absence of hypertension.

Although this data indicates that PA may be found in pre-hypertension, reliable evidence suggestive of a high prevalence is derived from the Framingham Offspring Study that evaluated the evolution of BP and basal aldosterone levels in 1688 normotensive individuals from 1995 to 1998 (74). Multivariable logistic-regression models based on quartiles of serum aldosterone levels were used to test for a linear trend in the risk of $\mathrm{BP}$ outcomes across quartiles. Aldosterone levels were directly associated with an increase in BP and the development of hypertension, with a $17 \%$ increase in the risk of hypertension per quartile increment in the serum aldosterone level (74). However, the prevalence of normotensive PA has prospectively been estimated only in our study of 100 normotensive, normokalaemic individuals who were followed up for 5 years; 11 of the 13 diagnosed with dysregulated aldosterone secretion (85\%) developed hypertension, compared with only 20 of $87(23 \%)$ without the diagnosis of PA (17). The results of this study in association with the results of the Framingham Offspring and other studies suggest that a sub-clinical form of PA may be present in a substantial proportion of normal individuals causing subtle cardiac dysfunction in the absence of hypertension.

\section{Conclusions}

It is now widely recognised that the prevalence of PA is substantially higher than previously believed. The identification and elimination of factors that could affect the performance characteristics of both screening and confirmatory tests of PA can greatly improve their diagnostic accuracy and reveal an even higher prevalence of PA in patients with hypertension. This view is reinforced further by the substantial reduction in arterial BP following the administration of MRAs in unselected hypertensive patients. In addition, the role that unrecognised forms of PA and stress-related aldosterone hypersecretion may exert in the development of hypertension needs to be further clarified. Although further studies are needed to verify these findings, it is possible that MR activation may be commonly related to the development of arterial hypertension.
Declaration of interest

The authors declare that there is no conflict of interest that could be perceived as prejudicing the impartiality of the review.

\section{Funding}

This review did not receive any specific grant from any funding agency in the public, commercial or not-for-profit sector.

\section{References}

1 Gordon RD, Gomez-Sanchez CE, Hamlet SM, Tunny TJ \& Klemm SA. Angiotensin-responsive aldosterone-producing adenoma masquerades as idiopathic hyperaldosteronism (IHA: adrenal hyperplasia) or lowrenin essential hypertension. Journal of Hypertension. Supplement: Official Journal of the International Society of Hypertension 19875 S103-S106.

2 Stowasser M, Gordon RD, Rutherford JC, Nikwan NZ, Daunt N \& Slater GJ. Diagnosis and management of primary aldosteronism. Journal of the Renin-Angiotensin-Aldosterone System 20012 156-169. (doi:10.3317/jraas.2001.022)

3 Rossi GP, Bernini G, Caliumi C, Desideri G, Fabris B, Ferri C, Ganzaroli C, Giacchetti G, Letizia C, Maccario M et al. A prospective study of the prevalence of primary aldosteronism in 1,125 hypertensive patients. Journal of the American College of Cardiology 200648 2293-2300. (doi:10.1016/j.jacc.2006.07.059)

4 Olivieri O, Ciacciarelli A, Signorelli D, Pizzolo F, Guarini P, Pavan C, Corgnati A, Falcone S, Corrocher R, Micchi A et al. Aldosterone to renin ratio in a primary care setting: the Bussolengo study. Journal of Clinical Endocrinology and Metabolism 200489 4221-4226. (doi:10.1210/jc.2003-032179)

5 Gordon RD, Stowasser M, Tunny TJ, Klemm SA \& Rutherford JC. High incidence of primary aldosteronism in 199 patients referred with hypertension. Clinical and Experimental Pharmacology \& Physiology 1994 21 315-318. (doi:10.1111/j.1440-1681.1994.tb02519.x)

6 Fardella CE, Mosso L, Gomez-Sanchez C, Cortes P, Soto J, Gomez L, Pinto M, Huete A, Oestreicher E, Foradori A et al. Primary hyperaldosteronism in essential hypertensives: prevalence, biochemical profile, and molecular biology. Journal of Clinical Endocrinology and Metabolism 200085 1863-1867. (doi:10.1210/jcem. 85.5.6596)

7 Stowasser M, Gordon RD, Gunasekera TG, Cowley DC, Ward G, Archibald C \& Smithers BM. High rate of detection of primary aldosteronism, including surgically treatable forms, after 'nonselective' screening of hypertensive patients. Journal of Hypertension 200321 2149-2157. (doi:10.1097/00004872-200311000-00025)

8 Mulatero P, Stowasser M, Loh KC, Fardella CE, Gordon RD, Mosso L, Gomez-Sanchez CE, Veglio F \& Young WF Jr. Increased diagnosis of primary aldosteronism, including surgically correctable forms, in centers from five continents. Journal of Clinical Endocrinology and Metabolism 200489 1045-1050. (doi:10.1210/jc.2003-031337)

9 Douma S, Petidis K, Doumas M, Papaefthimiou P, Triantafyllou A, Kartali N, Papadopoulos N, Vogiatzis K \& Zamboulis C. Prevalence of primary hyperaldosteronism in resistant hypertension: a retrospective observational study. Lancet 2008371 1921-1926. (doi:10.1016/ S0140-6736(08)60834-X)

10 Hannemann A, Bidlingmaier M, Friedrich N, Manolopoulou J, Spyroglou A, Volzke H, Beuschlein F, Seissler J, Rettig R, Felix SB et al. Screening for primary aldosteronism in hypertensive subjects: results from two German epidemiological studies. European Journal of Endocrinology 2012167 7-15. (doi:10.1530/EJE-11-1013)

11 Nishimura M, Uzu T, Fujii T, Kuroda S, Nakamura S, Inenaga T \& Kimura G. Cardiovascular complications in patients with primary 
aldosteronism. American Journal of Kidney Diseases 199933 261-266. (doi:10.1016/S0272-6386(99)70298-2)

12 Farquharson CA \& Struthers AD. Aldosterone induces acute endothelial dysfunction in vivo in humans: evidence for an aldosterone-induced vasculopathy. Clinical Science 2002103 425-431.

13 Rossi GP, Cesari M, Cuspidi C, Maiolino G, Cicala MV, Bisogni V, Mantero F \& Pessina AC. Long-term control of arterial hypertension and regression of left ventricular hypertrophy with treatment of primary aldosteronism. Hypertension 201362 62-69. (doi:10.1161/ HYPERTENSIONAHA.113.01316)

14 Williams JS, Williams GH, Raji A, Jeunemaitre X, Brown NJ, Hopkins PN \& Conlin PR. Prevalence of primary hyperaldosteronism in mild to moderate hypertension without hypokalaemia. Journal of Human Hypertension 200620 129-136. (doi:10.1038/sj.jhh.1001948)

15 Young WF. Primary aldosteronism: renaissance of a syndrome. Clinical Endocrinology 200766 607-618. (doi:10.1111/j.1365-2265.2007. 02775.x)

16 Stowasser M, Taylor PJ, Pimenta E, Ahmed AH \& Gordon RD. Laboratory investigation of primary aldosteronism. Clinical Biochemist. Reviews 201031 39-56.

17 Markou A, Pappa T, Kaltsas G, Gouli A, Mitsakis K, Tsounas P, Prevoli A, Tsiavos V, Papanastasiou L, Zografos G et al. Evidence of primary aldosteronism in a predominantly female cohort of normotensive individuals: a very high odds ratio for progression into arterial hypertension. Journal of Clinical Endocrinology and Metabolism 201398 1409-1416. (doi:10.1210/jc.2012-3353)

18 Lacroix A, Bourdeau I, Lampron A, Mazzuco TL, Tremblay J \& Hamet P. Aberrant G-protein coupled receptor expression in relation to adrenocortical overfunction. Clinical Endocrinology 201073 1-15. (doi:10.1111/j.1365-2265.2009.03689.x)

19 Mulatero P, Dluhy RG, Giacchetti G, Boscaro M, Veglio F \& Stewart PM. Diagnosis of primary aldosteronism: from screening to subtype differentiation. Trends in Endocrinology and Metabolism 2005 16 114-119. (doi:10.1016/j.tem.2005.02.007)

20 Funder JW, Carey RM, Fardella C, Gomez-Sanchez CE, Mantero F, Stowasser M, Young WF Jr \& Montori VM. Case detection, diagnosis, and treatment of patients with primary aldosteronism: an endocrine society clinical practice guideline. Journal of Clinical Endocrinology and Metabolism 200893 3266-3281. (doi:10.1210/jc.2008-0104)

21 Schirpenbach C \& Reincke M. Screening for primary aldosteronism. Best Practice \& Research. Clinical Endocrinology \& Metabolism 200620 369-384. (doi:10.1016/j.beem.2006.07.007)

22 Rossi GP, Barisa M, Allolio B, Auchus RJ, Amar L, Cohen D, Degenhart C, Deinum J, Fischer E, Gordon R et al. The Adrenal Vein Sampling International Study (AVIS) for identifying the major subtypes of primary aldosteronism. Journal of Clinical Endocrinology and Metabolism 201297 1606-1614. (doi:10.1210/jc.2011-2830)

23 Nanba K, Tamanaha T, Nakao K, Kawashima ST, Usui T, Tagami T, Okuno H, Shimatsu A, Suzuki T \& Naruse M. Confirmatory testing in primary aldosteronism. Journal of Clinical Endocrinology and Metabolism 201297 1688-1694. (doi:10.1210/jc.2011-2504)

24 Mulatero P, Milan A, Fallo F, Regolisti G, Pizzolo F, Fardella C, Mosso L, Marafetti L, Veglio F \& Maccario M. Comparison of confirmatory tests for the diagnosis of primary aldosteronism. Journal of Clinical Endocrinology and Metabolism 200691 2618-2623. (doi:10.1210/ jc.2006-0078)

25 Mulatero P, Milan A, Williams TA \& Veglio F. Mineralocorticoid receptor blockade in the protection of target organ damage. Cardiovascular \& Hematological Agents in Medicinal Chemistry 20064 75-91. (doi:10.2174/187152506775268776)

26 Westerdahl C, Bergenfelz A, Isaksson A \& Valdemarsson S. Captopril suppression: limitations for confirmation of primary aldosteronism. Journal of the Renin-Angiotensin-Aldosterone System 201112 326-332. (doi:10.1177/1470320310390405)

27 Ahmed AH, Cowley D, Wolley M, Gordon RD, Xu S, Taylor PJ \& Stowasser M. Seated saline suppression testing for the diagnosis of primary aldosteronism: a preliminary study. Journal of Clinical Endocrinology and Metabolism 201499 2745-2753. (doi:10.1210/jc. 2014-1153)

28 Mulatero P, Monticone S, Rainey WE, Veglio F \& Williams TA. Role of KCNJ5 in familial and sporadic primary aldosteronism. Nature Reviews. Endocrinology 20139 104-112. (doi:10.1038/nrendo.2012.230)

29 Lifton RP, Dluhy RG, Powers M, Rich GM, Cook S, Ulick S \& Lalouel JM. A chimaeric 11ß-hydroxylase/aldosterone synthase gene causes glucocorticoid-remediable aldosteronism and human hypertension. Nature 1992355 262-265. (doi:10.1038/355262a0)

30 Beuschlein F. Regulation of aldosterone secretion: from physiology to disease. European Journal of Endocrinology 2013168 R85-R93. (doi:10.1530/EJE-13-0263)

31 Al-Salameh A, Cohen R \& Desailloud R. Overview of the genetic determinants of primary aldosteronism. Application of Clinical Genetics 20147 67-79. (doi:10.2147/TACG.S45620)

32 Choi M, Scholl UI, Yue P, Bjorklund P, Zhao B, Nelson-Williams C, Ji W, Cho Y, Patel A, Men CJ et al. K+ channel mutations in adrenal aldosterone-producing adenomas and hereditary hypertension. Science 2011331 768-772. (doi:10.1126/science.1198785)

33 Beuschlein F, Boulkroun S, Osswald A, Wieland T, Nielsen HN, Lichtenauer UD, Penton D, Schack VR, Amar L, Fischer E et al. Somatic mutations in ATP1A1 and ATP2B3 lead to aldosterone-producing adenomas and secondary hypertension. Nature Genetics $2013 \mathbf{4 5}$ 440-442. (doi:10.1038/ng.2550)

34 Scholl UI, Goh G, Stolting G, de Oliveira RC, Choi M, Overton JD, Fonseca AL, Korah R, Starker LF, Kunstman JW et al. Somatic and germline CACNA1D calcium channel mutations in aldosteroneproducing adenomas and primary aldosteronism. Nature Genetics 2013 45 1050-1054. (doi:10.1038/ng.2695)

35 Azizan EA, Poulsen H, Tuluc P, Zhou J, Clausen MV, Lieb A, Maniero C, Garg S, Bochukova EG, Zhao W et al. Somatic mutations in ATP1A1 and CACNA1D underlie a common subtype of adrenal hypertension. Nature Genetics 201345 1055-1060. (doi:10.1038/ng.2716)

36 Scholl UI, Nelson-Williams C, Yue P, Grekin R, Wyatt RJ, Dillon MJ, Couch R, Hammer LK, Harley FL, Farhi A et al. Hypertension with or without adrenal hyperplasia due to different inherited mutations in the potassium channel KCNJ5. PNAS 2012109 2533-2538. (doi:10.1073/pnas.1121407109)

37 Boulkroun S, Beuschlein F, Rossi GP, Golib-Dzib JF, Fischer E, Amar L, Mulatero P, Samson-Couterie B, Hahner S, Quinkler M et al. Prevalence, clinical, and molecular correlates of KCNJ5 mutations in primary aldosteronism. Hypertension 201259 592-598. (doi:10.1161/ HYPERTENSIONAHA.111.186478)

38 Stowasser M. Primary aldosteronism and potassium channel mutations. Current Opinion in Endocrinology, Diabetes, and Obesity 2013 20 170-179. (doi:10.1097/MED.0b013e32835ef2fd)

39 Xekouki P, Hatch MM, Lin L, Rodrigo de A, Azevedo M, de la Luz Sierra M, Levy I, Saloustros E, Moraitis A, Horvath A et al. KCNJ5 mutations in the National Institutes of Health cohort of patients with primary hyperaldosteronism: an infrequent genetic cause of Conn's syndrome. Endocrine-Related Cancer 201219 255-260. (doi:10.1530/ERC-12-0022)

40 Taguchi R, Yamada M, Nakajima Y, Satoh T, Hashimoto K, Shibusawa N, Ozawa A, Okada S, Rokutanda N, Takata D et al. Expression and mutations of KCNJ5 mRNA in Japanese patients with aldosterone-producing adenomas. Journal of Clinical Endocrinology and Metabolism 201297 1311-1319. (doi:10.1210/jc.2011-2885)

41 Fernandes-Rosa FL, Williams TA, Riester A, Steichen O, Beuschlein F, Boulkroun S, Strom TM, Monticone S, Amar L, Meatchi T et al. Genetic spectrum and clinical correlates of somatic mutations in aldosterone-producing adenoma. Hypertension 201464 354-361. (doi:10.1161/HYPERTENSIONAHA.114.03419)

42 Gomez-Sanchez CE, Rossi GP, Fallo F \& Mannelli M. Progress in primary aldosteronism: present challenges and perspectives. Hormone and Metabolic Research 201042 374-381. (doi:10.1055/ s-0029-1243619) 
43 van Leeuwen N, Caprio M, Blaya C, Fumeron F, Sartorato P, Ronconi V, Giacchetti G, Mantero F, Fernandes-Rosa FL, Simian C et al. The functional c.-2G $>\mathrm{C}$ variant of the mineralocorticoid receptor modulates blood pressure, renin, and aldosterone levels. Hypertension 201056 995-1002. (doi:10.1161/HYPERTENSIONAHA.110.155630)

44 Fuchs-Hammoser R, Schweiger M \& Oelkers W. The effect of chronic low-dose infusion of ACTH (1-24) on renin, renin-substrate, aldosterone and other corticosteroids in sodium replete and deplete man. Acta Endocrinologica 198095 198-206.

45 Arvat E, Di VL, Lanfranco F, Maccario M, Baffoni C, Rossetto R, Aimaretti G, Camanni F \& Ghigo E. Stimulatory effect of adrenocorticotropin on cortisol, aldosterone, and dehydroepiandrosterone secretion in normal humans: dose-response study. Journal of Clinical Endocrinology and Metabolism 200085 3141-3146. (doi:10.1210/jcem. 85.9.6784)

46 Hattangady NG, Olala LO, Bollag WB \& Rainey WE. Acute and chronic regulation of aldosterone production. Molecular and Cellular Endocrinology 2012350 151-162. (doi:10.1016/j.mce.2011.07.034)

47 Xing Y, Parker CR, Edwards M \& Rainey WE. ACTH is a potent regulator of gene expression in human adrenal cells. Journal of Molecular Endocrinology 201045 59-68. (doi:10.1677/JME-10-0006)

48 Lin L, Hindmarsh PC, Metherell LA, Alzyoud M, Al-Ali M, Brain CE, Clark AJ, Dattani MT \& Achermann JC. Severe loss-of-function mutations in the adrenocorticotropin receptor (ACTHR, MC2R) can be found in patients diagnosed with salt-losing adrenal hypoplasia. Clinical Endocrinology 200766 205-210. (doi:10.1111/j.1365-2265. 2006.02709.x)

49 Reincke M, Beuschlein F, Latronico AC, Arlt W, Chrousos GP \& Allolio B. Expression of adrenocorticotrophic hormone receptor mRNA in human adrenocortical neoplasms: correlation with P450scc expression. Clinical Endocrinology 199746 619-626. (doi:10.1046/j. 1365-2265.1997.1991009.x)

50 Arnaldi G, Gasc JM, de Keyzer Y, Raffin-Sanson ML, Perraudin V, Kuhn JM, Raux-Demay MC, Luton JP, Clauser E \& Bertagna X. Variable expression of the $\mathrm{V} 1$ vasopressin receptor modulates the phenotypic response of steroid-secreting adrenocortical tumors. Journal of Clinical Endocrinology and Metabolism 199883 2029-2035. (doi:10.1210/jcem. 83.6.4873)

51 Lampron A, Bourdeau I, Oble S, Godbout A, Schurch W, Arjane P, Hamet P \& Lacroix A. Regulation of aldosterone secretion by several aberrant receptors including for glucose-dependent insulinotropic peptide in a patient with an aldosteronoma. Journal of Clinical Endocrinology and Metabolism 200994 750-756. (doi:10.1210/jc.2008-1340)

52 Kem DC, Weinberger MH, Gomez-Sanchez C, Kramer NJ, Lerman R, Furuyama $S \&$ Nugent CA. Circadian rhythm of plasma aldosterone concentration in patients with primary aldosteronism. Journal of Clinical Investigation 197352 2272-2277. (doi:10.1172/JCI107414)

53 Hoefnagels WH, Drayer JI, Smals AG, Benraad TJ \& Kloppenborg PW. Nocturnal, daytime, and postural changes of plasma aldosterone before and during dexamethasone in adenomatous and idiopathic aldosteronism. Journal of Clinical Endocrinology and Metabolism $1980 \mathbf{5 1}$ 1330-1334. (doi:10.1210/jcem-51-6-1330)

54 Zwermann O, Suttmann Y, Bidlingmaier M, Beuschlein F \& Reincke M. Screening for membrane hormone receptor expression in primary aldosteronism. European Journal of Endocrinology 2009160 443-451. (doi:10.1530/EJE-08-0711)

55 Androulakis II, Kaltsas GA, Kollias GE, Markou AC, Gouli AK, Thomas DA, Alexandraki KI, Papamichael CM, Hadjidakis DJ \& Piaditis GP. Patients with apparently nonfunctioning adrenal incidentalomas may be at increased cardiovascular risk due to excessive cortisol secretion. Journal of Clinical Endocrinology and Metabolism 201499 2754-2762. (doi:10.1210/jc.2013-4064)

56 Luger A, Deuster PA, Debolt JE, Loriaux DL \& Chrousos GP. Acute exercise stimulates the renin-angiotensin-aldosterone axis: adaptive changes in runners. Hormone Research 198830 5-9. (doi:10.1159/ 000181017)
57 Luger A, Deuster PA, Kyle SB, Gallucci WT, Montgomery LC, Gold PW, Loriaux DL \& Chrousos GP. Acute hypothalamic-pituitary-adrenal responses to the stress of treadmill exercise. Physiologic adaptations to physical training. New England Journal of Medicine 1987316 1309-1315. (doi:10.1056/NEJM198705213162105)

58 Kupari M, Hautanen A, Lankinen L, Koskinen P, Virolainen J, Nikkila H $\&$ White PC. Associations between human aldosterone synthase (CYP11B2) gene polymorphisms and left ventricular size, mass, and function. Circulation 199897 569-575. (doi:10.1161/01.CIR.97.6.569)

59 Davies E, Holloway CD, Ingram MC, Inglis GC, Friel EC, Morrison C, Anderson NH, Fraser R \& Connell JM. Aldosterone excretion rate and blood pressure in essential hypertension are related to polymorphic differences in the aldosterone synthase gene CYP11B2. Hypertension 199933 703-707. (doi:10.1161/01.HYP.33.2.703)

60 Piaditis GP, Kaltsas GA, Androulakis II, Gouli A, Makras P, Papadogias D, Dimitriou K, Ragkou D, Markou A, Vamvakidis K et al. High prevalence of autonomous cortisol and aldosterone secretion from adrenal adenomas. Clinical Endocrinology 200971 772-778. (doi:10.1111/j.1365-2265.2009.03551.x)

61 Gouli A, Kaltsas G, Tzonou A, Markou A, Androulakis II, Ragkou D, Vamvakidis K, Zografos G, Kontogeorgos G, Chrousos GP et al. High prevalence of autonomous aldosterone secretion among patients with essential hypertension. European Journal of Clinical Investigation 2011 41 1227-1236. (doi:10.1111/j.1365-2362.2011.02531.x)

62 Ye P, Mariniello B, Mantero F, Shibata H \& Rainey WE. G-proteincoupled receptors in aldosterone-producing adenomas: a potential cause of hyperaldosteronism. Journal of Endocrinology 2007195 39-48. (doi:10.1677/JOE-07-0037)

63 Albiger NM, Sartorato P, Mariniello B, Iacobone M, Finco I, Fassina A \& Mantero F. A case of primary aldosteronism in pregnancy: do LH and GNRH receptors have a potential role in regulating aldosterone secretion? European Journal of Endocrinology 2011164 405-412. (doi:10.1530/EJE-10-0879)

64 Gross MD, Grekin RJ, Gniadek TC \& Villareal JZ. Suppression of aldosterone by cyproheptadine in idiopathic aldosteronism. New England Journal of Medicine 1981305 181-185. (doi:10.1056/ NEJM198107233050401)

65 Mantero F, Rocco S, Opocher G, Armanini D, Boscaro M \& D'Agostino D. Effect of ketanserin in primary aldosteronism. Journal of Cardiovascular Pharmacology 19857 (Suppl 7) S172-S175. (doi:10.1097/00005344-198500077-00048)

66 Perraudin V, Delarue C, Lefebvre H, Do Rego JL, Vaudry H \& Kuhn JM. Evidence for a role of vasopressin in the control of aldosterone secretion in primary aldosteronism: in vitro and in vivo studies. Journal of Clinical Endocrinology and Metabolism 200691 1566-1572. (doi:10.1210/jc.2005-1453)

67 Rossi GP, Ganzaroli C, Cesari M, Maresca A, Plebani M, Nussdorfer GG \& Pessina AC. Endothelin receptor blockade lowers plasma aldosterone levels via different mechanisms in primary aldosteronism and high-to-normal renin hypertension. Cardiovascular Research $2003 \mathbf{5 7}$ 277-283. (doi:10.1016/S0008-6363(02)00658-2)

68 Mansmann G, Lau J, Balk E, Rothberg M, Miyachi Y \& Bornstein SR. The clinically inapparent adrenal mass: update in diagnosis and management. Endocrine Reviews 200425 309-340. (doi:10.1210/er.2002-0031)

69 Bernini G, Moretti A, Argenio G \& Salvetti A. Primary aldosteronism in normokalemic patients with adrenal incidentalomas. European Journal of Endocrinology 2002146 523-529. (doi:10.1530/eje.0.1460523)

70 Schwartz GL. Screening for adrenal-endocrine hypertension: overview of accuracy and cost-effectiveness. Endocrinology and Metabolism Clinics of North America 201140 279-294, vii. (doi:10.1016/j.ecl.2011.02.001)

71 Schwartz GL \& Turner ST. Screening for primary aldosteronism in essential hypertension: diagnostic accuracy of the ratio of plasma aldosterone concentration to plasma renin activity. Clinical Chemistry 200551 386-394. (doi:10.1373/clinchem.2004.041780)

72 Mulatero P, Monticone S, Bertello C, Mengozzi G, Tizzani D, Iannaccone A \& Veglio F. Confirmatory tests in the diagnosis of 
primary aldosteronism. Hormone and Metabolic Research 201042 406-410. (doi:10.1055/s-0029-1246186)

73 Newton-Cheh C, Guo CY, Gona P, Larson MG, Benjamin EJ, Wang TJ, Kathiresan S, O'Donnell CJ, Musone SL, Camargo AL et al. Clinical and genetic correlates of aldosterone-to-renin ratio and relations to blood pressure in a community sample. Hypertension 200749 846-856. (doi:10.1161/01.HYP.0000258554.87444.91)

74 Vasan RS, Evans JC, Larson MG, Wilson PW, Meigs JB, Rifai N, Benjamin EJ \& Levy D. Serum aldosterone and the incidence of hypertension in nonhypertensive persons. New England Journal of Medicine 2004351 33-41. (doi:10.1056/NEJMoa033263)

75 Lim PO, Dow E, Brennan G, Jung RT \& MacDonald TM. High prevalence of primary aldosteronism in the Tayside hypertension clinic population. Journal of Human Hypertension 200014 311-315. (doi:10.1038/sj.jhh.1001013)

76 Loh KC, Koay ES, Khaw MC, Emmanuel SC \& Young WF Jr. Prevalence of primary aldosteronism among Asian hypertensive patients in Singapore. Journal of Clinical Endocrinology and Metabolism 200085 2854-2859. (doi:10.1210/jcem.85.8.6752)

77 Mosso L, Carvajal C, Gonzalez A, Barraza A, Avila F, Montero J, Huete A, Gederlini A \& Fardella CE. Primary aldosteronism and hypertensive disease. Hypertension 200342 161-165. (doi:10.1161/ 01.HYP.0000079505.25750.11)

78 Papanastasiou L, Markou A, Pappa T, Gouli A, Tsounas P, Fountoulakis S, Kounadi T, Tsiama V, Dasou A, Gryparis A et al. Primary aldosteronism in hypertensive patients: clinical implications and target therapy. European Journal of Clinical Investigation 201444 697-706. (doi:10.1111/eci.12286)

79 Rossi GP, Bernini G, Desideri G, Fabris B, Ferri C, Giacchetti G, Letizia C, Maccario M, Mannelli M, Matterello MJ et al. Renal damage in primary aldosteronism: results of the PAPY Study. Hypertension 2006 48 232-238. (doi:10.1161/01.HYP.0000230444.01215.6a)

80 Westerdahl C, Bergenfelz A, Isaksson A, Nerbrand C \& Valdemarsson S. Primary aldosteronism among newly diagnosed and untreated hypertensive patients in a Swedish primary care area. Scandinavian Journal of Primary Health Care 201129 57-62. (doi:10.3109/02813432.2011.554015)

81 Seiler L, Rump LC, Schulte-Monting J, Slawik M, Borm K, Pavenstadt H, Beuschlein F \& Reincke M. Diagnosis of primary aldosteronism: value of different screening parameters and influence of antihypertensive medication. European Journal of Endocrinology 2004 150 329-337. (doi:10.1530/eje.0.1500329)

82 Ribeiro MJ, Figueiredo Neto JA, Memoria EV, Lopes MC, Faria MS, Salgado FN \& Oliveira TC. Prevalence of primary hyperaldosteronism in a systemic arterial hypertension league. Arquivos Brasileiros de Cardiologia 200992 39-45. (doi:10.1590/S0066-782X2009000100007)

83 Calhoun DA. Is there an unrecognized epidemic of primary aldosteronism? Pro Hypertension 200750 447-453. (doi:10.1161/ HYPERTENSIONAHA.106.086116)

84 Roger VL, Go AS, Lloyd-Jones DM, Benjamin EJ, Berry JD, Borden WB, Bravata DM, Dai S, Ford ES, Fox CS et al. Heart disease and stroke statistics - 2012 update: a report from the American Heart Association. Circulation 2012125 e2-e220. (doi:10.1161/CIR.0b013e31823ac046)

85 Xanthakis V \& Vasan RS. Aldosterone and the risk of hypertension. Current Hypertension Reports 201315 102-107. (doi:10.1007/ s11906-013-0330-y)

86 Zennaro MC, Rickard AJ \& Boulkroun S. Genetics of mineralocorticoid excess: an update for clinicians. European Journal of Endocrinology 2013 169 R15-R25. (doi:10.1530/EJE-12-0813)
87 Ducher M, Mounier-Vehier C, Baguet JP, Tartiere JM, Sosner P, Regnier-Le CS, Perez L, Fourcade J, Jabourek O, Lejeune S et al. Aldosterone-to-renin ratio for diagnosing aldosterone-producing adenoma: a multicentre study. Archives of Cardiovascular Diseases 2012 105 623-630. (doi:10.1016/j.acvd.2012.07.006)

88 Levy DG, Rocha R \& Funder JW. Distinguishing the antihypertensive and electrolyte effects of eplerenone. Journal of Clinical Endocrinology and Metabolism 200489 2736-2740. (doi:10.1210/jc.2003-032149)

89 Savoia C, Touyz RM, Amiri F \& Schiffrin EL. Selective mineralocorticoid receptor blocker eplerenone reduces resistance artery stiffness in hypertensive patients. Hypertension 200851 432-439. (doi:10.1161/ HYPERTENSIONAHA.107.103267)

90 Chapman N, Dobson J, Wilson S, Dahlof B, Sever PS, Wedel H \& Poulter NR. Effect of spironolactone on blood pressure in subjects with resistant hypertension. Hypertension 200749 839-845. (doi:10.1161/ 01.HYP.0000259805.18468.8c)

91 Iqbal J, Andrew R, Cruden NL, Kenyon CJ, Hughes KA, Newby DE, Hadoke PW \& Walker BR. Displacement of cortisol from human heart by acute administration of a mineralocorticoid receptor antagonist. Journal of Clinical Endocrinology and Metabolism 201499 915-922. (doi:10.1210/jc.2013-2049)

92 Achelrod D, Wenzel U \& Frey S. Systematic review and meta-analysis of the prevalence of resistant hypertension in treated hypertensive populations. American Journal of Hypertension 201528 355-3961. (doi:10.1093/ajh/hpu151)

93 Funder JW. Primary aldosteronism: are we missing the wood for the trees? Hormone and Metabolic Research 201244 251-253. (doi:10.1055/ s-0031-1301281)

94 Macfarlane DP, Yu N \& Leese GP. Subclinical and asymptomatic parathyroid disease: implications of emerging data. Lancet. Diabetes \& Endocrinology 20131 329-340. (doi:10.1016/S2213-8587 (13)70083-4)

95 Kaltsas G, Chrisoulidou A, Piaditis G, Kassi E \& Chrousos G. Current status and controversies in adrenal incidentalomas. Trends in Endocrinology and Metabolism 201223 602-609. (doi:10.1016/j.tem.2012.09.001)

96 Brooks RV, Felix-Davies D, Lee MR \& Robertson PW. Hyperaldosteronism from adrenal carcinoma. BMJ 19721 220-221. (doi:10.1136/ bmj.1.5794.220)

97 Medeau V, Moreau F, Trinquart L, Clemessy M, Wemeau JL, Vantyghem MC, Plouin PF \& Reznik Y. Clinical and biochemical characteristics of normotensive patients with primary aldosteronism: a comparison with hypertensive cases. Clinical Endocrinology 200869 20-28. (doi:10.1111/j.1365-2265.2008.03213.x)

98 Pappa T, Papanastasiou L, Kaltsas G, Markou A, Tsounas P, Androulakis I, Tsiavos V, Zografos G, Vamvakidis K, Samara C et al. Pattern of adrenal hormonal secretion in patients with adrenal adenomas: the relevance of aldosterone in arterial hypertension. Journal of Clinical Endocrinology and Metabolism 201297 E537-E545. (doi:10.1210/jc.2011-2874)

99 Stowasser M, Huggard PR, Rossetti TR, Bachmann AW \& Gordon RD. Biochemical evidence of aldosterone overproduction and abnormal regulation in normotensive individuals with familial hyperaldosteronism type I. Journal of Clinical Endocrinology and Metabolism $1999 \mathbf{8 4}$ 4031-4036. (doi:10.1210/jcem.84.11.6159)

100 Stowasser M, Sharman J, Leano R, Gordon RD, Ward G, Cowley D \& Marwick TH. Evidence for abnormal left ventricular structure and function in normotensive individuals with familial hyperaldosteronism type I. Journal of Clinical Endocrinology and Metabolism 200590 5070-5076. (doi:10.1210/jc.2005-0681)

Received 29 June 2014

Revised version received 2 December 2014

Accepted 23 December 2014 